\title{
Domain analysis of lipoprotein LppQ in Mycoplasma mycoides subsp. mycoides SC
}

\author{
Laetitia Bonvin-Klotz $\cdot$ Edy M. Vilei · Kathrin Kühni-Boghenbor · \\ Nadine Kapp $\cdot$ Joachim Frey $\cdot$ Michael H. Stoffel
}

Received: 3 May 2007 / Accepted: 6 July 2007 / Published online: 3 August 2007

(C) Springer Science+Business Media B.V. 2007

\begin{abstract}
The lipoprotein LppQ is the most prominent antigen of Mycoplasma mycoides subsp. mycoides small colony type (SC) during infection of cattle. This pathogen causes contagious bovine pleuropneumonia (CBPP), a devastating disease of considerable socio-economic importance in many countries worldwide. The dominant antigenicity and high specificity for M. mycoides subsp. mycoides SC of lipoprotein LppQ have been exploited for serological diagnosis and for epidemiological investigations of CBPP. Scanning electron microscopy and immunogold labelling were used to provide ultrastructural evidence that LppQ is located to the cell membrane at the outer surface of M. mycoides subsp. mycoides SC. The selectivity and specificity of this method were demonstrated through discriminating localization of extracellular (i.e., in the zone of contact with host cells) vs. integral membrane domains of LppQ. Thus, our findings support the suggestion that the accessible $\mathrm{N}$-terminal domain of LppQ is surface exposed and such surface localization may be implicated in the pathogenesis of CBPP.
\end{abstract}

L. Bonvin-Klotz · K. Kühni-Boghenbor .

N. Kapp · M. H. Stoffel

Division of Veterinary Anatomy, Vetsuisse Faculty, University of Bern, Postfach, 3001 Bern, Switzerland

L. Bonvin-Klotz · E. M. Vilei $(\square) \cdot$ J. Frey Institute of Veterinary Bacteriology, Vetsuisse Faculty, University of Bern, Postfach, 3001 Bern, Switzerland e-mail: edy.vilei@vbi.unibe.ch
Keywords Contagious bovine pleuropneumonia (CBPP) - Immunogold labeling · Lipoprotein LppQ · Domain analysis - Mycoplasma mycoides subsp. mycoides SC S Scanning electron microscopy (SEM)

\section{Abbreviations \\ CBPP Contagious bovine pleuropneumonia \\ SEM Scanning electron microscopy}

\section{Introduction}

Mycoplasma mycoides subsp. mycoides small colony type (SC) is an extra-cellular pathogen living in close association with host cells. It causes contagious bovine pleuropneumonia (CBPP), an acute, subacute or chronic infection of the respiratory system in cattle with a mortality rate of up to $30 \%$, causing severe losses in livestock production, in particular on the African continent (Provost et al. 1987; Food and Agriculture Organization of the United Nations 2003).

Lipoproteins are usually strongly antigenic membrane proteins known to play a central role in interactions between bacteria and eukaryotic cells, particularly with respect to adhesion, and to stimulate the release of pro-inflammatory cytokines (Mühlradt and Frisch 1994; Herbelin et al. 1994; Brenner et al. 1997; Marie et al. 1999; Calcutt et al. 1999; Belloy et al. 2003). Lipoproteins have been put forward as 
possible virulence factors of pathogenic mycoplasmas (Dyson and Smith 1997; Vilei et al. 2000; Pilo et al. 2003).

Membrane lipoprotein LppQ is the predominant antigen of $M$. mycoides subsp. mycoides SC and shows the strongest signal on immunoblots containing total antigen from this pathogen reacted with serum from cattle that have suffered from CBPP. It induces a specific, early and persistent immune response in infected animals (Abdo et al. 2000). LppQ is encoded as a precursor (of 445 amino acids) with a consensus sequence for prokaryotic signal peptidase II and a lipid attachment site (Figure 1). The leader sequence of LppQ shows a typical transmembrane structure with a significant helix formation capacity (Abdo et al. 2000). LppQ was shown to be a membrane protein by Triton $\mathrm{X}-114$ phase partitioning and lipidation was demonstrated by palmitic acid radiolabelling (Abdo et al. 2000). The C-terminal part of LppQ was found to possess repeated integral membrane structures rich in hydrophobic and aromatic amino acids, which have pore formation potential, and immunoblot analysis showed that the C-terminal domain possesses no particular immunogenicity, as serum derived from cattle naturally infected with M. mycoides subsp. mycoides SC did not react against it (Abdo et al. 2000). In contrast, the N-terminal domain of LppQ has three strongly hydrophilic domains and was shown to be the origin of the strong antigenic response against LppQ in naturally infected cattle. From these data, Abdo and collaborators deduced that the $\mathrm{N}$-terminal part of LppQ is exposed at the outer surface of M. mycoides subsp. mycoides SC (Abdo et al. 2000).

Due to the strong antigenicity of the extracellular $\mathrm{N}$-terminal part of LppQ and its specificity for M. mycoides subsp. mycoides $\mathrm{SC}$, a recombinant peptide comprising amino acids 22-218 of the LppQ precursor protein was used to develop a specific and sensitive ELISA assay for the serological detection of CBPP in cattle (Bruderer et al. 2002). Furthermore, LppQ seems to be involved in the inflammatory processes of $M$. mycoides subsp. mycoides SC, as cattle immunized with the recombinant peptide showed an increased susceptibility to infection with M. mycoides subsp. mycoides SC and exhibited more severe symptoms of CBPP than unvaccinated animals (Nicholas et al. 2004).

As LppQ is apparently involved in the molecular mechanisms of pathogenicity of $M$. mycoides subsp. mycoides SC (Nicholas et al. 2004; Pilo et al. 2006), we have investigated the topology of LppQ in M. mycoides subsp. mycoides SC by means of high resolution field emission scanning electron microscopy (SEM), with particular respect to the predicted localization of LppQ on the mycoplasmal cell surface. This technique allows proteins to be localized on mycoplasmas unequivocally and with high accuracy and resolution (Pilo et al. 2005). Here, we provide evidence that the $\mathrm{N}$-terminal part of LppQ is located on the surface of the mycoplasmal cell membrane and is accessible from the extracellular side while the C-terminal part of LppQ is not exposed.

\section{Materials and methods}

\section{Bioinformatic analysis}

Prediction of membrane topology was carried out by using the softwares TMpred (Hofmann and Stoffel 1993; http://www.ch.embnet.org/software/ TMPRED_form.html), TopPred (von Heijne 1992; http://bioweb.pasteur.fr/seqanal/interfaces/toppred.html) and Phobius (Käll et al. 2004; http://phobius.cgb.ki.se/). Protein secondary structure was predicted with the MINNOU software available on the web page http:// minnou.cchmc.org/ (Cao et al. 2006). Determination of the C-terminal repeats of lipoprotein LppQ was assessed by the MEME software version 3.5.4 at http:// meme.sdsc.edu/meme/meme.html (Bailey and Elkan 1994).

M. mycoides subsp. mycoides SC strain and sample preparation

M. mycoides subsp. mycoides SC strain Afadé was used in the present study. This strain was isolated in 1968 at Farcha Laboratory, N'Djamena, Chad, from a cow from Afadé, Northern Cameroon, which suffered from acute CBPP. The strain Afadé is known to be highly virulent (Vilei and Frey 2001) and was used 
A

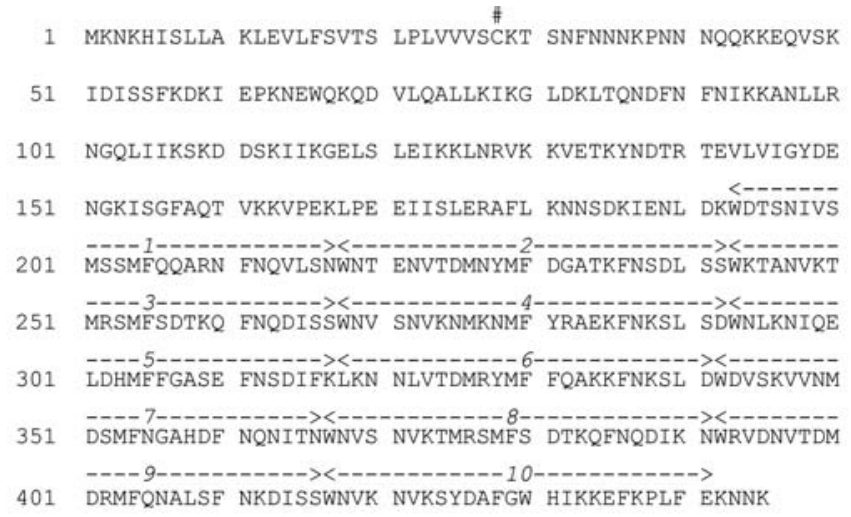

B

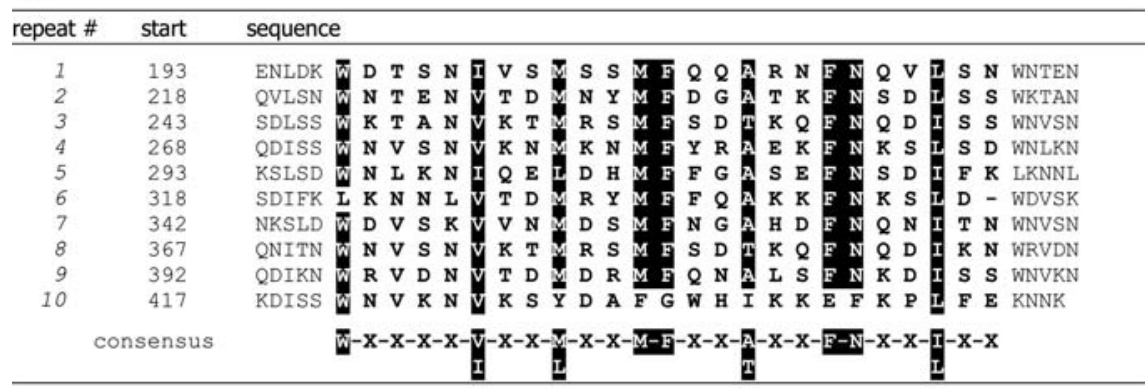

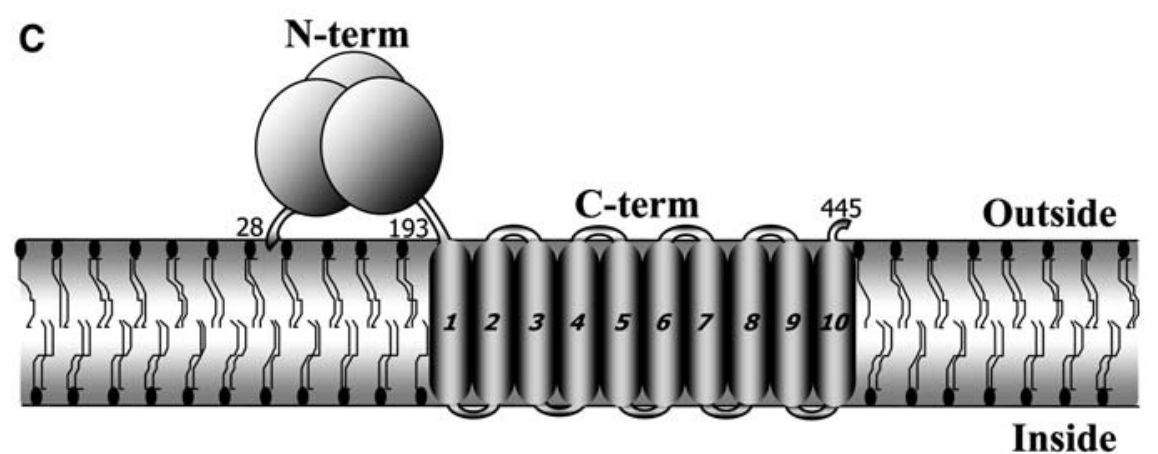

$W-X(4)-[V / I]-X(2)-[M / L]-X(2)-M-F-X(2)-[A / T]-X(2)-F-N-X(2)-[I / L]-X(2)$

Fig. 1 Structure of lipoprotein LppQ. (Panel A) LppQ protein sequence. Repeats are indicated by dashed arrows. The symbol \# corresponds to the signal peptidase II cleavage site, which allows for the obtainment of mature LppQ protein. (Panel B) The $10 \mathrm{C}$-terminal repeats rich in hydrophobic and aromatic residues, as identified with the MEME software, which build the transmembrane region of LppQ. Black background indicates conserved residues. The consensus sequence is shown. (Panel C) Model for protein topology of LppQ in the membrane lipid-bilayer of M. mycoides subsp. mycoides SC.

previously for experimental infection studies (Abdo et al. 1998). It was grown in standard mycoplasma medium (Axcell Biotechnologies, St. Genis l'Argen-
Repeat numbers and amino acid positions for the beginning of mature LppQ (28), the beginning of C-terminal portion (193) and the protein end (445) are indicated. The N-terminal part is supposed to be anchored in the lipid-bilayer by the lipid anchor of the $\mathrm{Cys}_{28}$ residue. The three hydrophilic domains of the Nterminal part, which were found with significant scores for coiled-coil tertiary structure (Abdo et al. 2000), are depicted as globular items. The C-terminal part consists of a transmembrane region built up of the 10 repeated integral membrane structures, whose consensus sequence is shown at the bottom

tière, France) by inoculation of $20 \mu \mathrm{l}$ of a frozen stock culture into $3 \mathrm{ml}$ of medium and incubation for 3 days at $37^{\circ} \mathrm{C}$. Growth and handling of live 
M. mycoides subsp. mycoides $\mathrm{SC}$ were performed in a biological safety laboratory fulfilling the BSL-3 containment safety standards.

Crude lysates were prepared by resuspending harvested mycoplasmas in TES buffer $(10 \mathrm{mM}$ Tris- $\mathrm{HCl}, 1 \mathrm{mM}$ EDTA, $0.8 \% \mathrm{NaCl}, \mathrm{pH} 8.0$ ) at a concentration of approximately $10^{9}$ cells $/ \mathrm{ml}$ (Abdo et al. 2000).

Production of antibodies against recombinant LppQ peptides

The polyhistidine-tagged recombinant peptides LppQ-N' (amino acids 22 to 218) and LppQ-C ${ }^{\prime}$ (amino acids 214 to 422) from the $\mathrm{N}$ - and $\mathrm{C}$-terminal portions of LppQ, respectively, were produced in Escherichia coli strain BL21(DE3) harbouring the respective plasmids as reported previously (Abdo et al. 2000; Bruderer et al. 2002). Recombinant peptides were polyhistidine-tagged at both their $\mathrm{N}$ - and C-termini. Purification of the peptides was performed by $\mathrm{Ni}^{2+}$ chelation chromatography and the purity of the peptides was analyzed by sodium dodecyl sulfate-polyacrylamide gel electrophoresis (SDS-PAGE).

Polyclonal monospecific sera directed against LppQ-N' and LppQ- $\mathrm{C}^{\prime}$ were obtained by subcutaneous immunization of rabbits with $160-200 \mu \mathrm{g}$ of purified recombinant polyhistidine-tagged peptides in $500 \mu \mathrm{l}$ of $50 \mathrm{mM}$ PBS buffer $\left(50 \mathrm{mM} \mathrm{Na} \mathrm{HPO}_{4} / \mathrm{NaH}_{2} \mathrm{PO}_{4}\right.$, $140 \mathrm{mM} \mathrm{NaCl}, \mathrm{pH}$ 8.0) mixed with $500 \mu \mathrm{l}$ of Adjuvant 10 (Gerbu Biotechnik GmbH, Gaiberg, Germany). Booster immunizations with 40 and $20 \mu \mathrm{g}$ of protein were performed 2- and 4-weeks later, respectively. The rabbits were bled 10 days after the last booster immunization and antisera were stored at $-20^{\circ} \mathrm{C}$.

Immunoglobulin $\mathrm{G}$ (IgG) fractions were purified from the two rabbit antisera with the HiTrap Protein $G$ kit (Amersham Pharmacia Biotech, Uppsala, Sweden) according to the manufacturer's instructions. Immunoglobulins from pre-immune sera were also purified. The purity of all IgGs was analyzed by SDS-PAGE. Protein concentrations were determined by using the method of Bradford (1976).

Immunoblot analysis

Whole cell antigens of strain Afadé were separated by $5-15 \%$ gradient SDS-PAGE (Ausubel et al. 1999) and blotted onto a nitrocellulose membrane with a pore size of $0.2 \mu \mathrm{m}$ (Bio-Rad Laboratories AG, Reinach, Switzerland). The membrane was blocked with $1 \%$ skim milk powder in TBS buffer (100 mM Tris- $\mathrm{HCl}, 150 \mathrm{mM} \mathrm{NaCl}, \mathrm{pH} 7.5$ ) for $60 \mathrm{~min}$ at room temperature. Strips were incubated with corresponding IgGs at a concentration of $1-2 \mu \mathrm{g} / \mathrm{ml}$ (diluted 1:2000) overnight at $4{ }^{\circ} \mathrm{C}$ and washed three times with TBS buffer for $5 \mathrm{~min}$. Serum obtained from a cow that was infected experimentally with M. mycoides subsp. mycoides SC strain Afadé (Abdo et al. 1998; diluted 1:100) or previously prepared (Abdo et al. 2000) rabbit hyperimmune sera directed against LppQ-N' and LppQ-C' (diluted 1:1000) were used as controls. The strips were incubated for $90 \mathrm{~min}$ at room temperature with alkaline phosphatase-labelled goat anti-rabbit $\operatorname{IgG}(\mathrm{H}+\mathrm{L})$ (Kirkegaard \& Perry Laboratories, Gaithersburg, MD, USA) diluted 1:2000 or monoclonal antibody anti-bovine $\operatorname{IgG}$ (Sigma, Buchs, Switzerland) diluted 1:5000 in skim milk buffer. The strips were washed three times with TBS buffer. The colour reaction was initiated with $0.3 \mathrm{mg} / \mathrm{ml}$ nitroblue tetrazolium (NBT) (Roche Diagnostics, Rotkreuz, Switzerland) and $0.15 \mathrm{mg} / \mathrm{ml}$ 5-bromo-4-chloro-3-indolyl phosphate (BCIP) (Roche Diagnostics) in alkaline buffer $\left(7 \mathrm{mM} \mathrm{Na}_{2} \mathrm{CO}_{3}, 3 \mathrm{mM}\right.$ $\mathrm{NaHCO}_{3}, 1 \mathrm{mM} \mathrm{MgCl}$, pH 9.6) and stopped with distilled water.

Preparation of M. mycoides subsp. mycoides SC for immunogold labelling

Coverslips that had been coated with gold or platinum and treated with poly-L-lysine (Sigma) to promote cell adhesion were immersed into $3 \mathrm{ml}$ of fresh standard medium in multiwell plates. Thereafter, $100 \mu \mathrm{l}$ of mycoplasma culture were added and the cultures were incubated for 5 to 6 days at $37^{\circ} \mathrm{C}$ until stationary phase. Coverslips with adhering mycoplasmas were washed three times with PBS buffer (2.9 mM NaH${ }_{2} \mathrm{PO}_{4}, 7.1 \mathrm{mM} \quad \mathrm{Na}_{2} \mathrm{HPO}_{4}, 137 \mathrm{mM}$ $\mathrm{NaCl}, \mathrm{pH} \mathrm{7.4)}$ at $37^{\circ} \mathrm{C}$ and fixed with $4 \%$ paraformaldehyde in PBS for $30 \mathrm{~min}$ at room temperature. After fixation, samples were washed with PBS buffer and blocked with $1 \%$ BSA and $0.2 \mathrm{M}$ glycine in PBS for $15 \mathrm{~min}$ at room temperature. Thereafter, mycoplasma cells were incubated with anti-LppQ-N' or anti-LppQ-C' IgGs diluted 1:100 $(30 \mu \mathrm{g} / \mathrm{ml})$ in PBS containing $1 \% \mathrm{BSA}$ overnight at $4^{\circ} \mathrm{C}$. After another 
washing step with PBS buffer for 5-10 min, mycoplasmas were labelled with $15 \mathrm{~nm}$ colloidal goldconjugated goat anti-rabbit antibody (British Biocell International, Cardiff, UK) diluted 1:50 in PBS for $90 \mathrm{~min}$ at room temperature. Coverslips were then washed with $0.1 \mathrm{M}$ cacodylate buffer $(\mathrm{pH} 7.4)$ and processed for SEM.

\section{Scanning electron microscopy}

Coverslips were incubated in $1.33 \%$ osmium tetraoxide with $0.11 \%$ ruthenium red in $0.13 \mathrm{M}$ cacodylate buffer ( $\mathrm{pH} 7.4$ ) for $15 \mathrm{~min}$, washed with $0.1 \mathrm{M}$ cacodylate buffer, dehydrated through an ascending ethanol series and dried by evaporation of hexamethyldisilazane (Sigma) as described previously (Stoffel et al. 1993; Stoffel et al. 2002; Stoffel and Friess 2002). Finally, they were mounted on metal stubs with a conductive adhesive (Provac AG, Balzers, Liechtenstein).

Samples were examined without further metal coating. Secondary electron micrographs and corresponding backscattered images were obtained with a fully digital field emission scanning electron microscope DSM 982 Gemini (Zeiss, Oberkochen, Germany) at an accelerating voltage of $5 \mathrm{kV}$, a working distance of $6-8 \mathrm{~mm}$ and a magnification from 50,000 to $100,000 \times$.

Control experiments included omission of primary antibody as well as the use of a rabbit anti-calcitonin antibody (Anawa, Zurich, Switzerland) and of IgGs from rabbit pre-immune sera as irrelevant substitutes for the anti-LppQ primary antibodies.

\section{Results}

Structure of the C-terminal domain of lipoprotein LppQ

Conventional predictors of membrane topology available online did not envisage the C-terminal domain of LppQ to be membrane-associated. However, determination of repeats in the LppQ protein sequence revealed that its $\mathrm{C}$-terminal domain, represented by the last 250 amino acids, consists of a region built up of 10 repeated units rich in hydrophobic and aromatic residues (Figure 1). These repeat units of 25 amino acids were all found to adopt a particular secondary structure consisting of helices of approximately 10 amino acids flanked upstream and downstream by amino acids forming random coils (not shown).

\section{Monospecificity of IgG preparations}

On immunoblots containing total antigen of M. mycoides subsp. mycoides SC strain Afadé, purified IgG preparations directed against the $\mathrm{N}$-terminal and against the C-terminal halves of LppQ each identified a single protein band with an apparent molecular mass of $48 \mathrm{kDa}$, which corresponds to the calculated size of $49.1 \mathrm{kDa}$ of LppQ (Figure 2). Reference rabbit hyperimmune sera directed against LppQ-N $\mathrm{N}^{\prime}$ and LppQ-C' ${ }^{\prime}$ collected almost a decade ago gave identical results. Control experiments with IgGs purified from pre-immune sera did not detect any corresponding antigen (Figure 2).

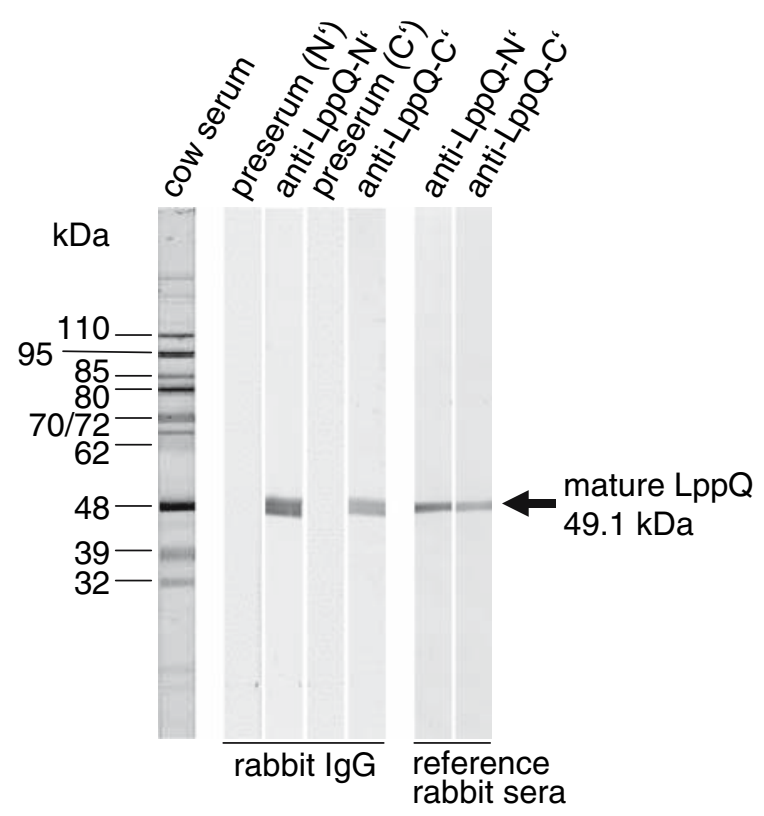

Fig. 2 Immunoblot analysis of total antigen of $M$. mycoides subsp. mycoides SC with anti-LppQ- $\mathrm{N}^{\prime}$ and anti-LppQ-C'. Approximately $10 \mu \mathrm{g}$ of total antigen of strain Afadé per lane was separated by $5-15 \%$ gradient SDS-PAGE, transferred onto a nitrocellulose membrane and probed with the serum from a cow infected experimentally with strain Afadé (Abdo et al. 1998), or with IgGs from rabbit pre-immune sera or from antisera against LppQ- $\mathrm{N}^{\prime}$ and $\mathrm{LppQ}-\mathrm{C}^{\prime}$, respectively. Reference rabbit hyperimmune sera directed against LppQ- $\mathrm{N}^{\prime}$ and LppQ-C' $C^{\prime}$ obtained almost a decade ago (Abdo et al. 2000) were also used. The arrowhead indicates the position of LppQ on the immunoblots 
Morphology of the mycoplasmas

Electron microscopy showed cultivated $M$. mycoides subsp. mycoides SC to be basically spherical in shape. They usually occurred as single cells but pairs or small groups of up to five organisms were also noted. Cell diameter varied between 200 and $500 \mathrm{~nm}$ and the cell surface was slightly grainy and irregular (Fig. 3A, C, E). Between fully grown microorganisms, small granular debris were observed.

\section{Immunogold labelling}

Labelling of mycoplasmas on coverslips with antiLppQ-N' antibodies yielded a SEM signal of moderate to high density at the cell surface (Fig. 3B). Specific labelling of granular debris was also present. In contrast, labelling with anti-LppQ- $C^{\prime}$ antibodies was absent in most of the cases (Fig. 3D) and appeared to be insignificant and coincidental in few cases (Table 1), as also observed in the three control experiments whereby labelling was investigated in the absence of primary antibodies and when preimmune serum or anti-calcitonin antibodies were used (Fig. 3F). Overall, there were significant differences between the number of particles labelled per cell by using anti-LppQ-N' antibodies and those labelled in the other four experiments $(P<0.0001$; Table 1)

\section{Discussion}

The goal of the present study was to discriminate the distribution of extracellular vs. integral membrane domains of lipoprotein LppQ in M. mycoides subsp. mycoides SC at the ultrastructural level. Amino acid sequence analysis for hydrophobicity by the method
Fig. 3 Scanning electron micrographs of $M$. mycoides subsp. mycoides SC with anti-LppQ- $\mathrm{N}^{\prime}$ and antiLppQ-C' antibodies. Secondary electron microscope images (A, C, E) reveal the spherical shape and rough cell surface of the mycoplasmas. Corresponding backscattered electron micrographs $(\mathbf{B}, \mathbf{D}, \mathbf{F})$ show indirect immunolabelling with $15 \mathrm{~nm}$ colloidal gold antibodies directed against the N-terminal extracellular domain of LppQ (B). In contrast, LppQ is not detected with anti-LppQ-C' antibody (D). Labelling is abolished when an anticalcitonin antibody is used as an irrelevant primary antibody (F)
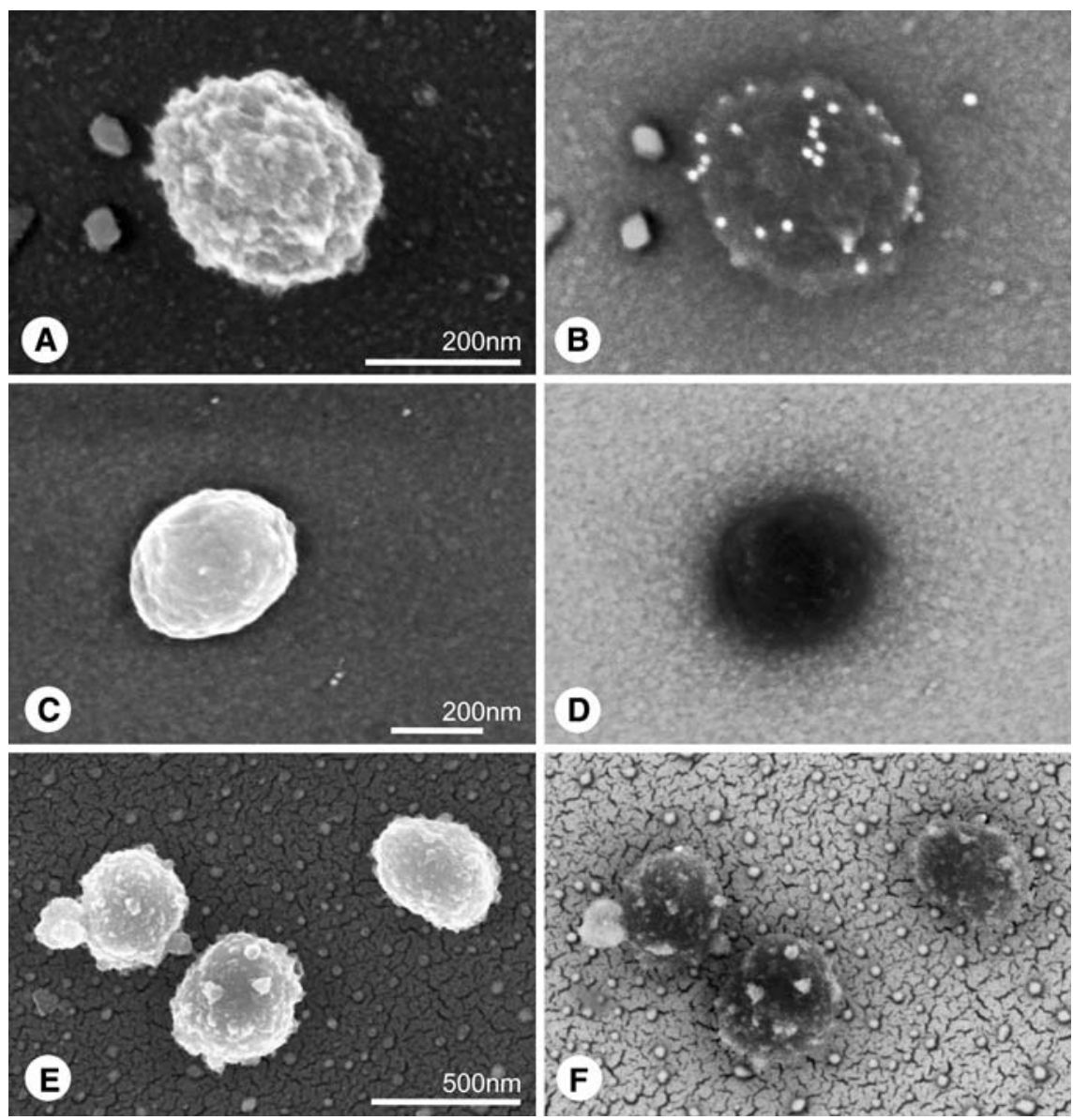
Table 1 Statistical analysis

\begin{tabular}{|c|c|c|c|c|c|}
\hline \multirow[t]{2}{*}{ Statistical data } & \multicolumn{5}{|l|}{ Treatment } \\
\hline & Anti-LppQ-N' & Anti-LppQ-C' & Anti-calcitonin & Pre-immune serum & No primary antibody \\
\hline Single cells investigated & 27 & 48 & 19 & 20 & 23 \\
\hline \multicolumn{6}{|l|}{ Labelled particles } \\
\hline Total & 333 & 17 & 6 & 7 & 5 \\
\hline Min & 2 & 0 & 0 & 0 & 0 \\
\hline $\operatorname{Max}$ & 31 & 4 & 3 & 3 & 2 \\
\hline Average per cell ${ }^{\mathrm{a}}$ & $12.33 \pm 7.58$ & $0.35 \pm 0.84$ & $0.32 \pm 0.82$ & $0.35 \pm 0.81$ & $0.22 \pm 0.52$ \\
\hline$P$-value ${ }^{\mathrm{b}}$ & & $<0.0001$ & $<0.0001$ & $<0.0001$ & $<0.0001$ \\
\hline
\end{tabular}

of Hopp and Woods (1981) revealed the N-terminal portion of LppQ to be particularly hydrophilic (Abdo et al. 2000). Thus, the lipidated N-terminal domain was predicted to be exposed at the extracellular surface of the plasma membrane (Abdo et al. 2000). On the other hand, the C-terminal portion consists of a region built up of 10 hydrophobic repeated units, and not nine as reported previously (Abdo et al. 2000). The repeat units were found to consist each of approximately 10 amino acids forming helices delimited on both sides with random coils, i.e. conformations without a regular secondary structure, and were not predicted to be membrane-associated by bioinformatic analysis. Since transmembrane helices are mostly composed of hydrophobic amino acid and the degree of hydrophobicity of the C-terminal domain of LppQ is clearly significant, the C-terminal portion was expected to be an integral membrane domain (Fig. 1). It has to be noted at this point that lipoproteins generally do not possess additional membrane-spanning domains (MSD) beyond their $\mathrm{N}$-terminal lipid anchors. However, there are relevant examples from Gram-positive bacteria, which contradict this general statement about lipoproteins and substantiate instead the occurrence of such additional MSDs. These examples include lipoproteins CtaC and QoxA of Bacillus subtilis (Bengtsson et al. 1999; Antelmann et al. 2001), as well as the proven lipoprotein of Mycoplasma pneumoniae $\mathrm{F}_{0} \mathrm{~F}_{1}$ ATPase (Pyrowolakis et al. 1998).

High resolution scanning electron microscopy in combination with immunogold labelling revealed extracellular epitopes with antibodies against LppQ$\mathrm{N}^{\prime}$ but no signal above the background of the three negative controls was detected with the antibody against LppQ-C'. These results substantiate the predicted localization of the two domains, as they unambiguously corroborate the accessibility of the $\mathrm{N}$-terminal domain at the extracellular side of the plasma membrane. The failure to immunolabel the C-terminal epitopes is an indication that they may be imbedded in the membrane. However, one cannot rule out the possibility that such epitopes (i) are buried in the centre of a globular protein, (ii) are masked by other surface components or (iii) are not recognized in their native forms by rabbit antibodies produced by inoculation of the recombinant peptide. Beyond providing ultrastructural evidence for the location of the hydrophilic and hydrophobic domains of LppQ, these results also demonstrate that immunogold labelling in scanning electron microscopy allows for subtle topographical discrimination and that selective visualization of peptides being exposed at the outer surface of microorganisms can be achieved with high accuracy and reliability.

The domain analysis of LppQ, which demonstrates the outstanding surface localization of the strongly hydrophilic N-terminal part of the lipoprotein, may explain the strong humoural response elicited by this lipoprotein during infection of cattle by $M$. mycoides subsp. mycoides SC (Abdo et al. 2000). It has to be demonstrated yet whether LppQ is also able to induce any cell-mediated immune response, as it is more often the case for cytoplasmic proteins. Absence of a 
cell-mediated immune response would explain the lack of protection in animals immunized with purified recombinant LppQ. In this respect, it should be noted that immunization of cattle with the purified recombinant N-terminal domain of LppQ elicited inflammatory processes of $M$. mycoides subsp. mycoides SC and exacerbated the clinical signs of CBPP after experimental infection compared to non-immunized animals (Nicholas et al. 2004).

\section{Conclusions}

Direct visualization of the N-terminal part of LppQ at the outer surface of M. mycoides subsp. mycoides SC, as demonstrated herein, provides evidence for the contention that LppQ is located to the extracellular side of the plasma membrane of mycoplasmas and that it is easily accessible by the humoural immune system of infected animals upon contact of host cells with $M$. mycoides subsp. mycoides SC.

Acknowledgements The technical support of Cynthia Furer, Yvonne Schlatter and Simon König is gratefully acknowledged. Part of this study and the contributions of JF and EMV were supported financially by Wellcome Trust, London, UK, grant $\mathrm{Nr} 075804$ "A genomic approach to understanding the immunopathology of contagious bovine pleuropneumonia (CBPP): improvement of current live vaccines and development of next generation vaccines".

\section{References}

Abdo E-M, Nicolet J, Frey J (2000) Antigenic and genetic characterization of lipoprotein LppQ from Mycoplasma mycoides subsp. mycoides SC. Clin Diagn Lab Immunol 7:588-595

Abdo E-M, Nicolet J, Miserez R, Gonçalves R, Regalla J, Griot C, Bensaide A, Krampe M, Frey J (1998) Humoral and bronchial immune responses in cattle experimentally infected with Mycoplasma mycoides subsp. mycoides small colony type. Vet Microbiol 59:109-122

Antelmann H, Tjalsma H, Voigt B, Ohlmeier S, Bron S, van Dijl JM, Hecker M (2001) A proteomic view on genomebased signal peptide predictions. Genome Res 11:14841502

Ausubel FM, Brent R, Kingston RE, Moore DD, Seidman JG, Smith JA, Struhl K (eds) (1999) Current protocols in molecular biology. John Wiley \& Sons, Inc., New York

Bailey TL, Elkan C (1994) Fitting a mixture model by expectation maximization to discover motifs in biopolymers. Proc Int Conf Intell Syst Mol Biol 2:28-36

Belloy L, Vilei EM, Giacometti M, Frey J (2003) Characterization of LppS, an adhesin of Mycoplasma conjunctivae. Microbiology 149:185-193
Bengtsson J, Tjalsma H, Rivolta C, Hederstedt L (1999) Subunit II of Bacillus subtilis cytochrome c oxidase is a lipoprotein. J Bacteriol 181:685-688

Bradford MM (1976) A rapid and sensitive method for the quantitation of microgram quantities of protein utilizing the principle of protein-dye binding. Anal Biochem 72:248-254

Brenner C, Wroblewski H, Le Henaff M, Montagnier L, Blanchard A (1997) Spiralin, a mycoplasmal membrane lipoprotein, induces T-cell-independent B-cell blastogenesis and secretion of proinflammatory cytokines. Infect Immun 65:4322-4329

Bruderer U, Regalla J, Abdo E-M, Huebschle OJB, Frey J (2002) Serodiagnosis and monitoring of contagious bovine pleuropneumonia (CBPP) with an indirect ELISA based on the specific lipoprotein LppQ of Mycoplasma mycoides subsp. mycoides SC. Vet Microbiol 84:195-205

Calcutt MJ, Kim MF, Karpas AB, Mühlradt PF, Wise KS (1999) Differential posttranslational processing confers intraspecies variation of a major surface lipoprotein and a macrophage-activating lipopeptide of Mycoplasma fermentans. Infect Immun 67:760-771

Cao B, Porollo A, Adamczak R, Jarrell M, Meller J (2006) Enhanced recognition of protein transmembrane domains with prediction-based structural profiles. Bioinformatics 22:303-309

Dyson D, Smith G (1997) Virulence of Mycoplasma mycoides mycoides (Sc). Vet Rec 140:348

Food, Agriculture Organization of the United Nations (2003) Contagious bovine pleuropneumonia. EMPRESS Transboundary Anim Dis Bull 24:2-7

Herbelin A, Ruuth E, Delorme D, Michel-Herbelin C, Praz F (1994) Mycoplasma arginini TUH-14 membrane lipoproteins induce production of interleukin-1, interleukin-6, and tumor necrosis factor alpha by human monocytes. Infect Immun 62:4690-4694

Hofmann K, Stoffel W (1993) TMbase - A database of membrane spanning proteins segments. Biol Chem Hoppe-Seyler 374:166-168

Hopp TP, Woods KR (1981) Prediction of protein antigenic determinants from amino acid sequences. Proc Natl Acad Sci USA 78:3824-3828

Käll L, Krogh A, Sonnhammer ELL (2004) A combined transmembrane topology and signal peptide prediction method. J Mol Biol 338:1027-1036

Marie C, Roman-Roman S, Rawadi G (1999) Involvment of mitogen-activated protein kinase pathways in interleukin8 production by human monocytes and polymorphonuclear cells stimulated with lipopolysaccharide or Mycoplasma fermentans membrane lipoproteins. Infect Immun 67:688-693

Mühlradt PF, Frisch M (1994) Purification and partial biochemical characterization of a Mycoplasma fermentansderived substance that activates macrophages to release nitric oxide, tumor necrosis factor and interleukin-6. Infect Immun 62:3801-3807

Nicholas RAJ, Tjipura-Zaire G, Mbulu RS, Scacchia M, Mettler F, Frey J, Abusugra I, Huebschle OJB (2004) An inactivated whole cell vaccine and LppQ subunit vaccine appear to exacerbate the effects of CBPP in adult cattle. Proceedings of the 3rd Meeting of the FAO-OIE-OAU/ 
IBAR-IAEA Consultative Group on CBPP. Towards sustainable CBPP control programmes for Africa (Rome, 12-14 November 2003). FAO, Rome, Italy, pp 91-97

Pilo P, Martig S, Frey J, Vilei EM (2003) Antigenic and genetic characterisation of lipoprotein LppC from Mycoplasma mycoides subsp. mycoides SC. Vet Res 34:761-775

Pilo P, Vilei EM, Peterhans E, Bonvin-Klotz L, Stoffel MH, Dobbelaere D, Frey J (2005) A metabolic enzyme as a primary virulence factor of Mycoplasma mycoides subsp. mycoides Small Colony. J Bacteriol 187:6824-6831

Pilo P, Frey J, Vilei EM (2006) Molecular mechanisms of pathogenicity of Mycoplasma mycoides subsp. mycoides SC. Vet J doi:10.1016/j.tvj1.2006.10.016

Provost A, Perreau P, Breard A, Le Goff C, Martel JL, Cottew GS (1987) Contagious bovine pleuropneumonia. Rev Sci Tech OIE 6:625-679

Pyrowolakis G, Hofmann D, Herrmann R (1998) The subunit b of the $\mathrm{F}_{0} \mathrm{~F}_{1}$-type ATPase of the bacterium Mycoplasma pneumoniae is a lipoprotein. J Biol Chem 273:2479224796

Stoffel MH, Friess AE (2002) Demonstration and cytochemical analysis of anionic sites on ejaculated boar spermatozoa: a scanning electron microscopy study using cationised colloidal gold. Histochem Cell Biol 117:61-67

Stoffel MH, Frethem C, Hamilton DW, Friess AE (1993) Improved preservation of rat epididymal sperm for highresolution low-voltage scanning electron microscopy (HR-LVSEM). Mol Reprod Dev 34:175-182

Stoffel MH, Busato A, Friess AE (2002) Density and distribution of anionic sites on boar ejaculated and epididymal spermatozoa. Histochem Cell Biol 117:441-445

Vilei EM, Frey J (2001) Genetic and biochemical characterization of glycerol uptake in Mycoplasma mycoides subsp. mycoides SC: its impact on $\mathrm{H}_{2} \mathrm{O}_{2}$ production and virulence. Clin Diagn Lab Immunol 8:85-92

Vilei EM, Abdo E-M, Nicolet J, Botelho A, Gonçalves R, Frey J (2000) Genomic and antigenic differences between the European and African/Australian clusters of Mycoplasma mycoides subsp. mycoides SC. Microbiology 146:477-486 von Heijne G (1992) Membrane protein structure prediction. Hydrophobicity analysis and the positive-inside rule. J Mol Biol 225:487-494 